\title{
Valerie Solanas and the Queer Performativity of Madness
}

\author{
Desireé D. Rowe and Karma R. Chávez
}

\begin{abstract}
Accusations of madness have long been hurled at queer and feminist bodies, and typically when people are deemed mad, they are granted little agency. This article attempts to read madness as potentially agentic when it manifests as what we call a "queer performativity of madness." Using the writing of and rhetoric surrounding Valerie Solanas, the infamous radical feminist known for shooting Andy Warhol, we develop the notion of a queer performativity of madness and show how historical figures like Solanas read against the binary oppositions that often create our understanding of sexuality, reason, and politics. Though madness does not always supply agency, we suggest that rethinking madness offers fruitful resources for feminist and queer theory.
\end{abstract}

\section{Keywords}

agency, unreason, politics of knowing, binary oppositions, Foucault

George Coates staged a revolution in January of 2000. On a small stage in San Francisco, the lights went up on "Up Your Ass," a raucous performance piece written by Valerie Solanas, the woman popularly known for shooting Andy Warhol in 1968. Having been rediscovered by Coates, the San Francisco premiere was the first time Solanas's script had ever seen the lights of the stage. Coates staged "Up Your Ass" a second (and final) time at P.S. 122, a world- renowned performance art space in New York City in 2001. The second performance saw reviews in major publications, including the Village Voice. The Voice saw power in Solanas's words: "what astonishes more is the ahead-of-its-time cri- tique of gender roles and sexual mores embedded in the jol- lity. Queer theory has nothing on the boundary-smashing glee of Solanas's dystopia, where the two-sex system is packed off to the junkyard" (Solomon, 2001, para. 3). Time Out New York recognized this performance as "one of the sassiest enjoyable shows around right now," proclaiming it the Critics' Pick of the week but asking the reader to "forget that the author of this play was a homicidal loon who almost killed a famous artist because she thought he'd stolen her writing" (Cote, 2001, para. 4). To facilitate this forgetting, Coates added his own flavor to Solanas's script. He changed the setting to an outdoor karaoke café, built in pop tunes with cleverly reworked lyrics (from Patsy Cline to Led Zeppelin), and, in general, contributed a bit of humor to Solanas's oft-perceived militant diatribes.

Coates did not merely produce this performance forrave reviews. He was working for a cause. In an interview with

Salon.com on February 23, 2000, Coates tells how he picked Solanas's show for a double bill with Arthur Miller's The Archbishop's Ceiling as performances against censor- ship from the National Endowment for the Arts. Coates explains his rationale for putting the two seemingly dispa- rate shows back-to-back, "if I do a double-book, that is, two shows together, and one of them is a show that is censored today and another is about censorship in another culture, do they inform each other in some way?" (Moore, 2000, p. 48). Coates' choice to place Solanas and Miller against each other creates an easy comparison between the two. On his death in 2005, the lights on Broadway dimmed for Arthur Miller, a widely respected U.S. playwright (Berger, 2005). To continue the contrast, when Solanas died in 1988, her death went virtually unnoticed and, most certainly, did not include a lengthy obituary in the New York Times. Coates' choice to juxtapose Miller and Solanas to make an argu- ment about censorship is informative in another way as the contrast also calls on Solanas's "madness" to evidence the "normalcy" of other artists. That a queer "madwoman" plays opposite a canonized male playwright further entrenches a connection between queerness, feminism, and madness that is often used within popular culture to high- light and augment that which is "normal." At the same time, however, it is in this typical juxtaposition that agency also emerges.

This is an essay about queerness and madness and the subversive possibilities located within the queer performa- tivity of madness. With some rare exceptions (Cixous, 1976; Irigaray, 1985; Schlichter, 2003), madness is almost always construed negatively when attached to queer and feminist bodies, whether in literature or by institutional dis- courses (Baym, 1984; Coffman, 2006; Gilbert \& Gubar, 1979; Love, 2001; Walsh, 2002). Such negative delinea- tions seem logical as the material consequences for being deemed mad undoubtedly stunt agency and the possibility for one's viability in a given society. Nevertheless, the ambagious logic of madness, defined against a norm, which then in turn defines anyone outside the norm as mad, relies on a binary, perhaps several binaries. As with all binary log-ics, one part of the binary - madness - not only helps con- stitute the meaning for normality but also represses the subservient part of the binary. Deconstructing the binaries 
that render the negative discourse of madness so powerful opens the possibility for a subversive understanding of cer- tain performative constitutions of madness. We suggest that a queer performativity of madness may be a subversive form of madness that has much to offer our thinking about feminists and queer theorists' relationship to this construct. To advance this argument, we begin by introducing readers to Valerie Solanas. Next, we review the binaries that uphold the negative construction of madness within the scholarly literature. Then, by working through a close reading of Solanas's rhetoric, we supply our definition of a "queer per- formativity of madness" to evidence the subversive possi- bilities of this rereading of her madness as agentic. We end with the implications of this argument for feminist and queer theories as well as for those who recreate the lives of queer and mad historical figures.

\section{Valerie Solanas}

Solanas, a White radical feminist of the late 1960s, left behind no "great speeches" or autobiographies. Left, how- ever, are fragments of a life fraught with misogyny, mad- ness, and brilliance. Solanas left behind no close friends who could share stories of their time together. The only place to turn was the scattered fragments of her life and her ideology. Notes she had written to Warhol, clippings of newspaper interviews, a single published article, SCUM, her handwritten notes in the New York Public Library's copy of SCUM, and her unpublished manuscript "Up Your Ass" create this milieu of scraps, fragments, and assorted pieces of paper that shape Solanas. There is no collection devoted to this radical feminist; and as Deem (1996) aptlyobserves, this is perhaps no accident, "Grasping at frag- ments is necessary given the modes of conservatism which dominate the fields of reference for contemporary public discourse and painfully restrict the space of feminism within the political" (p. 513). Solanas's work is not accepted in traditional feminist records, offering it no stable home and perpetuating fragmentation. The Duke University's online collection of archives from the Women's Liberation Movement, considered to be the foremost archives of the time, dismisses her in a footnote: "While Solanas is not generally considered to be part of the Women's Liberation Movement, her SCUM (Society to Cut Up Men) Manifesto, written in 1967, is an example of extreme radical feminist theory" (http://scriptorium.lib. duke.edu/wlm/). Duke's unwillingness to archive Solanas's materials perpetuates the disjointedness of Solanas's own historiography. We are not attempting to put the pieces back together as McGee (1990) suggests of textual fragmenta- tion where "the apparently finished discourse is in fact a dense reconstruction of all the bits of other discourses from which it was made. It is [instead] fashioned from what we can call "fragments"' (p. 279). Rather, the impossibility of reconstructing an assumed truth of Solanas's subjectivity speaks to the form of this piece. Although we cannot pres- ent a narrative culled from objective and established texts, there is a story of Solanas, one that deserves to be told.

Solanas, a woman engaged with and denounced by the radical feminist movement, was born on April 9, 1936, in Atlantic City. Solanas grew up in Ventnor, New Jersey, an impoverished neighborhood outside of Atlantic City. Her parents, Dorothy Biondi and Louis Solanas, lived in this working-class neighborhood until their death. Clara Shields, a neighbor of Solanas when they were younger, remem- bered Solanas "with a mixture of affection and bemuse- ment," as a girl who hit a boy who was tormenting a younger girl and was kicked out of Holy Cross Academy for hitting a nun (Harron, 1996, p. xi). At fourteen, Solanas went to boarding school where she had her first lesbian experience. According to Harron (1996), years later she "told her pub- lisher Maurice Girodias that she had only been in love once in her life, with a girl she met at boarding school" (p. xii). Throughout her life, Solanas never claimed a sexual orien- tation; rather, she resented anyone who sought to do the claiming for her. After only a few years in boarding school, Solanas returned to her hometown and attended Oxen Hill High School in Maryland. After high school, Solanas went on to attend the University of Maryland.

In college, Valerie majored in psychology. Harron (1996) interviewed a college friend of Solanas who remembered, "she was one of only two students in their class who had a

4.4 grade point average" (p. xi). Solanas attended college in the mid-1950s and worked as a prostitute. She was also a member of the honor society and someone who was "terrifi- cally angry and terrifically funny" (Heller, 2001, p. 172). 
After college, Solanas was admitted to the University of Minnesota to get her master's degree in biology. By the next year, Solanas dropped out. According to her sister, "she said there was nothing relevant to women, all the professorships were for men, all the research places for men. She said it was no way to gain a higher education" (Doyle, 2006, p. 32). Little is known about Solanas from 1957 to 1965. In these eight years, Solanas hitchhiked back to the east coast, and, by 1965, Solanas was living in Greenwich Village and earn- ing money as a prostitute.

By 1967, Solanas had written SCUM Manifesto and met Andy Warhol for the first time. By the spring of 1968, through peddling her manifesto on the street, Solanas had sold at least four hundred copies (Rich, 1993). Harron inter- viewed the photographer Nat Finkelstein who "first brought Valerie to the Factory, and that it [the shooting] was some- thing of an act of revenge, since he knew how difficult Valerie was" (Harron, 1996, p. xviii). Solanas's "difficulty" could have been easily misinterpreted as a desire to move up the social ladder. In 1967, Solanas was living in the Chelsea Hotel, panhandling and still working as a prosti- tute. In fact, "By the time her movements in New York took her to Warhol's Factory, she had already achieved notoriety, having been interviewed by the Village Voice as the proto-feminist author of this scabrous tract $[S C U M]$ " (Doyle, 2006, p. 32). Solanas's efforts at distribution had given her notoriety in radical feminist circles around New York. She had written two full-length manuscripts, SCUM and "Up Your Ass," and had an article published in the softcore men's magazine Cavalier.

It is unclear when, between 1967 and June 1968, Solanas gave Warhol a copy of "Up Your Ass," her as yet unpublished script. Solanas was eager for Warhol to read the text; he was turning toward film and she wanted him to produce her script. Warhol eventually cast Solanas in his 1967 film I, A Man as an aggressive, raunchy lesbian. Perhaps, the I, A Man character was Warhol's way of sating Solanas. By the time he paid her US\$20 for her role, she was beginning to pester him about his review of the script.

On June 3, 1968, Solanas marched into Andy Warhol's Factory. By this time, Warhol had all but banned Solanas from entering the Factory because she called nearly every day pestering him about the now lost script. Walking into the lobby, Solanas saw Warhol and art dealer Mario Amaya. When they could not produce her script, she fired her .32 caliber pistol at them five times. Solanas hit Warhol twice and Amaya once, sending them both to the hospital. Solanas quickly turned and left the Factory leaving behind a brown paper bag with her address book and a sanitary napkin inside (Doyle, 2006). After surrendering herself to the police, media inundated Solanas with attention. When asked why she shot Warhol, Solanas explained, "He had too much control over my life" (Doyle, 2006, p. 32). The reporters asked further about Solanas's motivations and she replied, "I have a lot of very involved reasons. Read my Manifesto" (Harding, 2001, p. 147). After the June 5th hearing, Solanas was placed in Elmhurst Psychiatric Hospital, under the care of Dr. Ruth Cooper (The Andy Warhol Museum, 2006). It is widely believed that Solanas did not receive extended jail time because Warhol refused to testify against her. Little is known about Solanas after her three years in the psychiatric hospital. Until the late 1970s, Solanas could be found sleeping on stoops in St. Mark's Place in New York City. In 1971, Olympia Press released another edition of SCUM Manifesto with an introduction by Vivian Gornick.

Eventually, Solanas moved to San Francisco, and, on April 25, 1988, Solanas's body was found at 56 Mason Street, a welfare

hotel in the slums of San Francisco (Harron, 1996). She was presumed dead from a sexually transmitted disease. Valerie would have never wanted her life framed around the single act of shooting Andy Warhol. There was more to her than that single psychotic moment that catapulted her into popular culture notoriety. In the next section, we briefly review scholarship on queerness, women, and madness before articulating what was more about Solanas than shooting Warhol, by reading her life and work through a framework we call the "queer performativity of madness."

\section{Queers, Women, and Madness}

Queer scholars have long worked to sever the links between homosexuality and both madness and mental illness. Many of these discussions pertain to the pathologization of male homosexuality. Most famously, as some scholars conjecture, Foucault's genealogy of the discursive formation of madness likely relates to his perspectives on the pathologization of homosexual practices (Eribon, 2001; Foucault, 1988). Early psychoanalytic theories, such as Lacan's theory of psychosis, link homosexuality to madness in the form of mental illness (Bruhm, 1996). As Foucault sug-gests, psychoanalysts assumed that all madness finds its origin in some sort of problem with sexuality (Eribon, 2001). Other medical, psychiatric, and psychological theories also construct homosexuality or homosexual practice as related or endemic to mental illness. Outside of institutional discourses, links between homosexuality and mental illness have long pervaded the social imaginary (Stockton, 2007) and continue to in certain circles that champion reparative therapies or cures for homosexuality. Queer scholars challenge these linkages and demonstrate how such connections both emerge from and reinforce heteronormativity and trace the development of these relation- ships. Though scholars like Foucault relish labels such as "mad philosopher," he also spent much of his career unpacking the impacts of madness and related discourses of "unreason" (Eribon, 2001, p. 34; Huffer, 2010). For the most part, such analyses of madness emphasize the power

of the discourse as a negative and oppressive force. Relatedly, many such investigations reinscribe the relationship between queerness and homosexuality (Schlichter, 2007). Such investigations often equate queer with homosexual identity, urges, or practices. Though such scholarship may work to sever the links between madness and queerness, it simultaneously strengthens the association between queerness and homosexuality and, thereby, minimizes the existence or 
relevance of other sorts of queer performances and queer sexualities.

In addition to the equation of (male) homosexuality and madness, scholarly writings that discuss women, and especially lesbian or queer women, often analyze how negativity, loneliness, moroseness, and insanity are connected with lesbian desire in film and literary texts as well as in the lives of famous White women such as Virginia Woolf, Charlotte Mew, and others (Coffman, 2006; Love, 2001; Walsh, 2002). Although lesbianism and other forms of women's nonheterosexual desire receive scant attention compared with that written about men, because of the long-standing and historical connections between all forms of mental illness and often White female bodies more generally, these discussions are especially potent (Caminero-Santangelo, 1998; Felman, 1993; Gilbert \& Gubar, 1979). Very often these analyses center on the figure of the "madwoman," and many demonstrate or insist on the impossibility of subversion in connection with madness as it is connected with misogyny. Feminist scholars often understand the madwoman as a victim of patriarchal oppression. Feminist psychologist Phyllis Chesler was in fact the first to demarcate a "double standard" of mental health, which disadvantages women and sees (White) masculinity as the standard of mental wellness (Chesler, 1977). Within literary criticism, the famous book, The Madwoman in the Attic, discusses how women writers faced the contradiction of authority and authorship as male and their own positions as writers with inferior locations in society.

More recent scholarship continues to examine the link- ages between women, especially lesbian or gender-nonnormative women, and madness and how these connections become especially pervasive and oppressive on several dis- cursive registers. Much of this scholarship focuses on issues of representation. For example, in following the argument of Derrida that madness is "what by essence cannot be said," Coffman (2003) discusses how any investigation of accounts of madness may be "complicit in the violence through which the figure of the 'madwoman' is constructed" (p. 416). In reviewing the framing of Christine Papin, a French maid accused of both lesbian incest and slaying the mistress and daughter of the home where she served in 1933, Coffman suggests the difficulties of framing in mediated and literary representations of madness. For example, she notes that in the case of the film, Les blessures assassines, which depicts the case of Papin, there are other possible explanations for Papin's predicament. These include poverty, losing relation- ships with her father and sister after the father is accused of molesting the sister, and an attempted assault by her moth- er's new lover. Despite these other possible explanations for her behavior, the film produces Papin as a madwoman. Moreover, as Coffman maintains, the film dichotomizes its own sobriety in relation to the madwoman without questioning its role in the constitution of Papin's madness (p. 423). This critique applies to any representation of madness that reduces it to individuality without also indicting systemic dysfunction. The tragedy of this "madwoman" thus exists from the entrapment of her poverty and social positioning, the discontent of her "madness," and the representation of Papin by those who retell her story.

In addition to scholarship that examines media and literary representations of the tragedies of madness, some have examined how the reception of historical White women, often authors and lesbians, swerve in and out of discourses of madness. For instance, in Walsh's discussion of poet Charlotte Mew's closeted lesbianism and her fears of becoming insane, she shows how themes of insanity both emerge in Mew's poetry and in the unusual way she lived her life (Walsh, 2002). Both her lived experiences and her poetry often centered on the body's instability and its fail- ures. Often Mew attempted to reconcile these concerns with the narrators of her poems, and, yet, as Walsh concludes, the fears that compelled Mew to write were never shed, as a preoccupation with her own body's fallibility consumed her. Nonetheless, Walsh praises as a lesson to future poets Mew's ability to voice her struggles over such fears.

In accounts of both the representation of madness and the ways madness constitutes particular women (and often lesbians) in negative ways, some scholars subvert the pes- simistic narrative and investigate the productive potential of such madness. Schlichter (2003) challenged the thesis of many feminist scholars who denounce the trope of the madwoman as contrary to feminist struggle. Instead, she sug- gests that the figure of the madwoman can aid in creating "a paradoxical politics of enunciation" which defies and cri- tiques masculine representation (p. 312). Her analysis of Kathy Acker's writing demonstrates how Acker's depiction of woman in relation to madness actually provides repre- sentations of "woman" that challenge the association of women with negativity and supply options for at leastsome women to define femininity for themselves (p. 320).

Schlichter's work is important for two key reasons. First, in developing the subversive notion of "critical madness," she confronts the binary between madness and normality by providing a divergent reading of performances of madness. Second, in advancing the idea of "queer" or "dissident" heterosexuality, Schlichter (2007) disrupts the logic of queerness equaling homosexuality. We find these two animations especially fruitful in broadening queer and feminist understandings of madness. Although both queer and feminist scholars critique the constructions of madness and its connections with feminist and queer subjects, few take the move of locating madness as subversive. Moreover, in Schlichter's connection of queerness with heterosexuality, she invites a complication of expectations of queer gender and sexual performances, which is useful in analyzing Solanas who cannot easily be described as heterosexual, lesbian, or bisexual. By conjoining two of Schlichter's theoretical ideas, we contend that the queer madwoman critiques not only White masculinity but also heteronormative representation and domination. In a discursive field that certainly acknowledged Solanas's legitimate struggles with mental illness, but primarily constituted her as a mad- woman, Solanas adopted a queer performative relationship to such discourses, and such performativity enabled the possibilities for her agency as a public voice. By under- standing Solanas's queer performativity of madness, we suggest we have access to her unique type of feminine/ feminist agency as well as how her queer performativity of madness helps to rearticulate links between homosexuality and queerness, madness and homosexuality, and femininity and madness. As we analyze Solanas, we develop this framework. 


\section{Queer Performativity of Madness}

To understand precisely what a queer performativity of madness looks like, we will first turn toward Solanas's published work in Cavalier magazine. Through her writing, Solanas ruptures traditional binaries and illustrates Sedgewicks' "politics of unknowing" and pushes us to think of queer in terms of madness rather than the tradi- tional homosexual/heterosexual binary. After reviewing how madness is popularly received, we explore how Solanas herself has been labeled as mad. Through her own works, we next claim, Solanas evokes a queer performativ- ity of madness. This performativity is one that ruptures traditional politics of knowing (both madness and queer- ness) and is based on performative slippages.

\section{Seeking Solanas, Investigating Text: Binary Oppositions and Queer Theory}

In 1966, Solanas published a piece in Cavalier magazine, which by the 1960s had evolved into a monthly soft-core heterosexual men's magazine. Solanas's piece, For 2 $\phi$ : Pain, works against the traditional understanding of what is published in a soft-core magazine. For 2 $\phi$ : Pain tells the story of a successful female panhandler who "hits" only men for change, charges them for conversation and sex, and has lengthy conversations with female pamphleteers on why they do not distribute to women. Much of what is known about Solanas is reflected in this story, and, as such, we read this as autobiographical. The tone of the piece is sharp considering the context. Solanas (1966) begins the piece as follows:

Being fresh out of college, I found myself in the typically feminine dilemma of carving out for myself in a male world a way of life appropriate to a young woman of taste, cultivation and sensitivity. There must be nothing crass-like work. However, a girl must survive. So, after a cool appraisal of the social scene, I finally hit up an excellent occupation, challenging to the ingenuity, dealing on one's own terms with people and affording independence, flexible hours, great stability and, most important, a large amount of leisure time, an occupation highly appropriate to female sensibilities. (p. 38)

Marked by a heavy satirical impulse, the piece befits a typical lowbrow men's magazine with its inclusion of Solanas taking money for sex with women in front of men and with the men themselves. But it also subverts, threatening an inclusion of queerness and working to engage queerness in such a heteronormative space. Solanas is not gay or straight, and though she engages with heterosexual and homosexual sex and desire, she offers no distinction between or denunciation of either of them. Solanas, as Ronell notes in her 2004 introduction to SCUM Manifesto, "introduces static and interference on every possible refer- ential stronghold without, however, loosening her grip on the troubled signifiers she has in her sights" (p. 7). The static here is clear. Solanas, in a magazine aimed at men looking to "get off," has written a satirical piece mocking them. Creating Ronell's "static and interference," Solanas writes herself into this 1966 issue of Cavalier. We know that Solanas worked as a prostitute much of her life (Deem, 1996; Harron, 1996; Ronnell, 2000). Considering this piece tells the story of a prostitute living in New York City and mirrors Solanas's language use in SCUM, we can at least concede that this piece shares much of the same linguistic intensity that Solanas would have adopted. In the piece, after asking a "hit" for money, Solanas offers her own thoughts:

"Sure, Sweetie, here." (It’s my wild body—gets them almost every time)

"Pardon me, Sir, do you have fifteen cents?" (I don't say it's for carfare, unless they ask; the preciousness of my time demands brevity)

"Could I interest you in some dirty words?" (I have a corner on the market.)

“Tiene usted quince centavos?” (Few can escape.) (Solanas, 1966, p. 40) 
We mark these moments because they rupture the stereo- typical relationship between the subordinate prostitute (female) and the hit (male). In each of these exchanges, Solanas pulls apart the traditional binary understanding of this relationship and pushes it further away from conventional discourses. We do not often hear the honest side of the prostitute, free from fanciful titillation, in a soft-core porno- graphic magazine in 1966. Solanas gives this to us and begins our discussion of her relationship to queertheory.

As with post-structuralist theory, queer theory often takes as its starting point the rupturing of binary oppositions. As Sedgwick (1990) argues, "Western culture has placed what it calls sexuality in a more and more distinctively privileged relation to our most prized constructs of individual identity, truth, and knowledge" (p. 3). Furthermore, Sedgwick maintains that sexuality is often assignable as either "a homo- or a heterosexuality," one which is binarized and thus ripe with implications (Schlichter, 2003, p. 320). A primary effect of this binary arrangement is an "epistemological privilege of unknowing" that allows for an ignorance of those in positions of power in relationships to those on the marginalized side of the binary (Sedgwick, 1990, p. 5). Solanas's writing in Cavalier attempts to forge a politic of knowing through authorial force-rupturing the privilege of the binary.

After confronting a woman who only hands out pamphlets on a public lecture to men because they "well ... you know, seem intellectual," the narrator remarks "I must admit I'm impressed; she's been programmed beautifully" a "nice, middleclass lady, one of Betty Friedan's 'privileged, educated' girls" (Solanas, 1966, p. 77). Here Solanas uses a forum that is aimed at those couched in Sedgwick's privi- lege of unknowing, the typical men's magazine. As the reader moves through the piece, Solanas's queerness emerges in how she engages others, questioning and critiquing along the way. Queerness, for Solanas, is a rupturing of the binary.

Another moment where Solanas threatens a breakdown of unknowing is while the narrator teaches another woman the art of panhandling. The novice "approaches a guy accompanying a woman: 'Do you have fifteen cents?" and the narrator quickly corrects her, "Don't hit on a guy with a broad. Like he's gonna let her know he's a mark?" (Solanas, 1966, p. 76). Through the publication of this piece, Solanas winks at those men reading Cavalier. That wink is a threat of knowing and the power of unmasking.

The binary is always unstable because of the reliance on unknowing or keeping queerness away from heterosexuality so there can be a (at least somewhat) valid claim of ignorance. Solanas threatens to refuse to keep the distance. The constant need for heterosexuality to be ignorant of the politics of homosexuality allows for the heterosexual matrix to remain a dominant force of power. This ignorance of homosexuality allows homophobia to take charge and remain in power. For example, the spread of panic during the HIV/ AIDS crisis in relationship to how gay men "behave" was based on an ignorance of homosexuality that was endorsed by the Reagan administration and eventually led to the banning of queer blood (Bennett, 2009). There was little actual knowledge; rather, there was a rampant spread of homophobia through dominant matrices of power. The threat of "queerness" then is a threat of breaking down the binary relationship and relying on a politic of knowing. Knowing, in the way we are advancing, is an understanding of the per- formative power of identity. As Sedgwick (1990) argues, the hetero/homo binary has had a significant impact on a wide array of social constructions, and one of the only way to interrogate these constructions is "historical de- and recon- textualization" (p. 12). This is where we turn to Solanas. For she allows us to queer our understanding of madness, we perform a politic of knowing rather than unknowing.

\section{Madness}

In many ways, the notion of madness epitomizes the reli- ance on binaries that are derivative of the hetero/homo construction. The madwoman is an archetypical representa- tion that works toward "enabling and outlining the locus of the masculine subject of reason, while simultaneously epito- mizing a negation of women's discursive authority" (Schlichter, 2003, p. 310). We contend that the power of the epistemological privilege of unknowing keeps the mad- woman at bay, marking her as other/outsider without agency. This is seen in reactions to Solanas prior to shooting Warhol, where some already constructed her as a mad- womanoutsider. In an interview conducted before the shooting of Warhol, but published afterward, the interviewer notes, "Unlike most single girls of her generation she has decided exactly what her usefulness in life should be. She has dedicated the remainder of her life to the avowed pur- pose of eliminating every single male from the face of the earth" (Marmorstein, 1968, p. 9). Knowing nothing of Solanas besides her distributing the Manifesto, the author wrote Solanas's narrative for her, by marking her looks, "not an unusual looking woman with clear brown eyes," in con- trast with her goals that were "unlike most single girls of her generation" creating a portrait of woman engulfed in mad- ness through difference (Marmorstein, 1968, p. 10). These constructions of Solanas are an example of the politic of unknowing. Solanas, though, takes these descriptions and rupturesqueers - them forcing us to see the other side of the narrative. Though also unmarked, Solanas's Whiteness also features here, as her difference is a racialized one as she fails to adopt the norms of White femininity.

As Foucault (1995) explains, "madness is language that is excluded - those who, against the code of language, pro- nounce words without meaning (the 'insane,' the 'imbe- ciles,' the 'demented'), or those who utter sanctified words 
(the 'violent ones,' the 'furious'), or yet still those who bring forth forbidden meanings (the 'libertines,' the 'head- strong')" (p. 295). As one of the "headstrong," Solanas is already constructed as mad through racialized and gendered constructions of what is normal. Solanas adds "violent" and "furious" to Foucault's list of signifiers after the shooting of Warhol and the large-scale distribution of her text. Although we acknowledge that her shooting of Warhol was a violent act, our attempt to reread constructions of madness is wrapped up in what Solanas was before (and after) the shooting. Because of her move outside of the normal, she was already strange, weird, headstrong; in essence, mad.

We see Solanas's primary constitution of self (both prior to and after the shooting of Warhol) as a madwoman also complicated by gendered representations. As Schlichter (2003) maintains, "The madwoman, one of the stereotypes of femininity in modern Western culture, holds a central position within the gendered system of representation, enabling and outlining the locus of masculine subject of reason, while simultaneously epitomizing a negation of women's discursive authority" (p. 310). Solanas defied traditional representations of female madness, going beyond the typical neurotic feminine implications. For Solanas, there is no fragile moment of breakdown, "butch-dykey, angry, poor, and fucked up: who could ask for anything more?" (Ronnell, 2000, p. 17). In this way, Solanas isn't the (White and straight) woman in the attic who is mad as a product of her isolation. At the same time, as evidenced above, Solanas also does not fit the trope of the mad homosexual. Her queer- ness ruptures both norms of femininity and sexuality and how they are typically equated with madness.

After the shooting of Warhol, New York City newspapers rushed into action to detail the chronology and the characters involved. The Daily News interviewed friends of Warhol, the first being Ultra Violet, one of Warhol's super- stars within his Factory. She explained, "This underground movie world is a mad, mad world with a lot of mad people in it. Maybe this girl, Valerie, was mad herself" (Faso, McLaughlin, \& Henry, 1968, p. 3). Ultra Violet character- izes Solanas as mad, but just like everyone else. But Violet is quickly dismissed by "another who said Valerie has a strong, masculine will and added: 'I hated her" (Faso, McLaughlin, \& Henry, 1968, p. 32). The vitriol in "I hated her" can be attributed to Solanas shooting Warhol and is easily understood considering the context. The other addi- tion, however, that of the "strong, masculine will" placed in conversation with the discovery of Solanas's madness via Ultra Violet paints a picture of a woman who people dis- liked because she was, as Foucault noted, headstrong and unfeminine. These are the two key facets of the character- izations of Solanas as mad.

As we discussed earlier, woman-as-mad is a popular trope that dominant discourses constantly reinforce. Our turn toward Solanas, however, seeks to destabilize that trope. Via a clear marking of Solanas's characterizations as gendered, we now seek to show how Solanas engaged in a type of performativity of madness that she called on for a type of credibility within the world. The trope of the mad- woman is so predominate Ultra Violet believed that anyone involved in the "underground movie world" could be mad. Solanas's gendered body creates the madwoman persona, one that had a much more illicit power.

The difficulty with any analysis of madness is the limita- tion of discourse, how can we talk about Solanas and mad- ness

without reifying the binary constructions that we are so diligently working against? Schlichter has the same problem when she concludes, "The theorist appears to be complicit with patriarchical representations because her alternatives seem to be limited to either to submitting to masculinist rationality by reproducing the discourse of reason or to ful- filling the patriarchal image of femininity as madness" (Schlichter, 2003, p. 311). To answer our own challenge, we view Solanas's madness as, at times, performative.

\section{Performativity}

Butler's theory of gender performativity draws on Derridean notions of citationality and iterability, particularly as laid out in his critique of speech-act theory's proponent, Searle, as Searle assumes that context can be seen through text (Butler, 1999; Derrida, 1977). When applied to gender, Butler explains that performativity is "acts, gestures, and desire that produce the effect of an internal core or substance, but pro- duce this on the surface of the body" (Butler, 1999, p. 173). Gender subjectivity is discursively constituted, and through "stylized repetition," gender appears as if it is natural and normal. Gender is constituted within the heterosexual matrix, and the heterosexual matrix operates under the logic that sex leads to gender, which leads to (opposite-sex) desire, and individuals are compelled to conform to this logic.

However, Butler (1995) explains that there are slippages, "junctures where discourse is renewed," and, in such spaces, agency for alternative performances can be created. Each iteration of a performative act has the potential to be a moment of alterity. Originally coined by Derrida, a moment of alterity is a difference in the repetition. These changes in the pattern offer a possibility of change or a slippage. Slippages "haunt signification as its abject borders or as that which is strictly foreclosed: the unlivable, the nonnarrativiz- able, the traumatic" (Butler, 1993, p. 188). These slippages shape the final push of performativity because the slippages destabilize discourse rather than constantly reproduceit.

In July 1977, well after shooting Warhol and spending three years in Elmhurst Psychiatric Hospital, the Village Voice interviewed Solanas. Her discussion with Howard Smith and Brian Van der Horst (1977) in the "Scenes" col- umn illustrates the dimension of Solanas's performativity of madness: 
Valerie Solanas (VS): In the first place, I don't want to get into a big interview, because I'm not into giving free interviews. I would like you to mention in your column that I'm going to give an interview to the periodical that makes the highest offer that's above a certain minimum that I have in mind.

Scenes: Which is what? VS: I don't want to say Scenes: Then can they bid?

VS: They can bid. Just say its crazy. Just say Valerie wanted to make this crazy remark and-you know, say that.

Scenes: You'll offer, what, a full interview detailing everything?

VS: No, no. Wait, I didn't say that. I just said I'll give an interview. That's all. Let me just leave it at this - I will give

an interview to the periodical making the highest offer. (p. 32)

We mark this interview excerpt as a slippage. Solanas's understanding of her own madness as sensational, newsworthy, and, of course, lucrative is illuminating. This is a queer performativity of madness. To remain a public figure, Solanas must remain interesting. Her madness is trumpeted to keep her story in circulation and to remain credible. Solanas is explicit with her indications that her madness is still present and viable when she tells the reporters to "just say Valerie wanted to make this crazy remark" by maintaining the public's perception of her madness, Solanas knew she could profit. This is characteristic of a slippage then because she is pulling her own madness into a politic of knowing.

As Solanas actually committed a violent act, was sentenced to a psychiatric facility for treatment and then released, her performance of madness is credible. As Huffer (2010) notes, "queer performativity dialectically unravels the subject's interiority as 'sex,' but leaves intact the internalizing violence that produces the moral soul" (p. 116). The "Scenes" interview offered a behind-the-scenes moment of candor where Solanas is determined to let the public know that even though she has been through treatment, she will still say and do "crazy" things. Her knowing and saying that she will perform madness is the queering of madness itself - the slippage. This is not to deemphasize Solanas's internalized violence (the shooting of Warhol), her understanding of the power of self-declaring madness, and our own cultural obsession with it. "Madness, in turn, is the rarer danger, a chance that weighs little compared with the obsessions it has engendered and the questions it has been asked. How could it be, in a culture, that such a slight contingency held such great power of revelation and terror" (Foucault, 1995, p. 292). Solanas, at this point in her life, is now using madness to remain in the public eye and retain credibility. To work against the reinscription of binary representations, Solanas's madness must be read through a lens of queer performativity of madness.

\section{Agency}

We see Solanas's queer performativity as a marker of an alternative construction of agency, one that is precarious, potent, and contradictory in its process. As Rand (2008) mentions, rhetorical agency emerges from a position of undecidability and shifting context. Unlike the polemic, the narrative of Solanas's life is fraught with moments engaging the epistemological privilege of unknowing and attempting to move past it or overthrow it - queering it. Her queer performativity of madness is jerky, unpredictable, and fraught with complications (such as shooting Warhol) but does mark her engagement with this posthumanist vision of agency.

Rand (2008) works toward an understanding of the queerness of agency framed through "a means for emphasizing and exploring the riskiness and undecidability of acting, and as an actualization of the queerness of rhetorical agency" (p. 312). Agency, in this way, turns away from traditional humanist approaches that are centered on a specific subject that is formed in relation to external forces. Even as she seemingly works to subvert this position, Campbell can be seen as an exemplar of this traditional position, one that engages the humanist subject-centered understanding of agency in con- junction with recognition of external forces. Campbell's (2005) feminist approach recognizes "the force of external constraints, such as subject positions constituted by power" and the ways context shifts how individuals move in the world (p. 4). Campbell's move can be used as a bridge to Rand's constructivist work on agency. Following a more constructivist position allows for a decentering of the essence of the subject and an emphasis on a subjectivity that does not rely on an essence. Rather, the subject is constantly being constructed through discourse, context, and history. Although there is a clear understanding of the social construction of the subject, what is important is a distinction of what the relation- ship is between agency and thatconstruction.

Rand, using Larry Kramer as her "text," proposes a queering of agency that rests on the polemic as a queer form. As Rand (2008) explains, "redeeming the polemic's productivity as a rhetorical form - regardless of content takes seriously the centrality of risk and unpredictability to agency" (p. 314). Rand's articulation of agency centered on the polemic is based in a long history of the polemicist being the harbinger of productive discourse through debate and lively discussion. Framing Kramer through this light, Rand's spin on Campbell's "promiscuous and protean" construction of agency is that it is also queer. Queer, for Rand, is not a sexual label. Rather, in conjunction with the polemic, queer becomes a way of understanding agency as a "potentially disruptive and radical force" (Rand, 2008, p. 314).

Although we agree with Rand's (2008) invocation of queerness away from that which is sexual, we cannot abide with Rand's final takeaway; "a performance of the unpre- dictability of uptake, force, and effects - the queerness of rhetorical agency - that I propose is the condition of possi- bility for any rhetorical act" (p. 315). In Rand's framing, any rhetorical act cannot be seen as queer because of the use of the polemic. The polemic, ranging from Socrates to the present, does not work for all subjects. Rand's use of Kramer ignores the implications of his White, male, monied body on the effectiveness of him as a polemicist. 
Solanas's slipping in and through madness can be seen two ways. First, as a woman who struggles with mental illness, Solanas does not have agency over the disease when she shoots Warhol. We are not attempting to make the point that Solanas's shooting Warhol was a performance of agency. Rather, shooting Warhol lies in contrast to what Solanas became after hospitalization: not "cured," but a woman who was aware of the power of the performative slippages of a woman-who-is-mad. This is seen in the previously mentioned interview where Solanas performs mad. She has seen the publicity and notoriety that the trope of madwoman achieved for her and she uses it to her own benefit. We mark these moments of Solanas's knowing as performative slippages that queer the public's sense of madness, for with a queer performativity there is a "promise of political agency in the hyperbolic redeployment of gendernorms that constitute a subject" (Huffer, 2010, p. 119).

Unwilling (and perhaps unable) to return to a "normal" life after the shooting of Warhol, Solanas (perhaps unwit- tingly) continued the performance. People constructed her as mad before the shooting and she continued to be seen as mad within mainstream media after her treatment, so, in effect, what could she do? She attempted to capitalize on her notoriety (like many people do today) as mad. Performing it again - becoming "rebelliously remade: she is joker, trickster, a sassy artist who operates in the camp mode of ironic subversion" (Huffer, 2010, p. 120).

\section{Conclusion}

Solanas may serve as an ideal type to demonstrate the possibilities of a queer performativity of madness because she was a subject constituted so squarely within/by discourses of queerness and madness. Yet Solanas is by far not the only queer or feminist construed as mad. Often, for queer feminists and especially women of color, madness is inscribed on their bodies, whether they perform in ways that actually resemble madness. In other words, because of the challenge to normative structures that both queer and feminist politics pose, those enacting such politics and related identities are constituted in and by a discursive field of madness. In addition to being a queer feminist, Solanas also worked through legitimate struggles with mental illness, which, as we have demonstrated here, further figured her as mad. In this way, Solanas's queer performativity of madness was not a willful performance enacted by a knowing agent, yet she was also not without agency as she performed a queer madwoman. Being constituted by, and also repeating the discourse of madness as Solanas did, suggests a particular sort of queer politics that potentially highlights the subversive potential of performativity. As feminist and queer scholars have long worked against the stain of madness as it perpetually lingers on feminist and queer bodies and texts, we hope to have demonstrated that a queer performativity of madness offers an alternative way to think about the agentic possibilities of madness and possible links between other public manifestations of nonnormative behavior and queer/feminist politics and theory.

Queer and feminist politics have, in differing ways, sought to rupture the normativity of, among others, sexist and

heterosexist systems. Because of the normativity of sexism and heterosexism, work that seeks to dismantle their power is easily construed within the mainstream as crazy. And yet, as written in a different context by Black feminists Audre Lorde and bell hooks, just as the mainstream tries to relegate extremely negative emotions and behaviors to the margins, rage and anger also have profound political utility (hooks, 1995; Lorde, 1984). Similarly, we argue that queer performativity of madness has political usefulness for chal- lenging the construal of particular people as mad and there- fore outside of the realm of reason. Although Solanas certainly enacted behaviors that are easily defined as mad, the way in which she picked up the discourse of madness to etch out a public space for her voice is noteworthy. And though her written works such as SCUM Manifesto might have otherwise been lost in history, the queer feminist poli- tics outlined in Solanas's works remains at least minimally part of the public sphere. Though one would not likely want to develop a feminist politics solely from the writing of Solanas, her radical words as found in her manifesto articu- late a corrective to more mainstream and normative forms of politics. Queer theory, in particular, has long been articu- lated as a theory that challenges the normal (Warner, 1999), and so queer performativities of madness may provide visions for nonnormative worlds beyond what rational engagements with politics and theory provide.

Scholars of queer theory and critical disability studies have already demarcated the ways in which heteronormativity and able-bodiedness are interlocking systems of invisibility and power (McRuer, 2003; West, 2010). Yet, as McRuer notes, there are several intersections with critical disability studies and queer theory. For example, bringing critical disability within queer theory might challenge the figuring of queerness and disability as weakness and lack and the cultural devaluation of both. Such an alliance does not deny the materiality of queer or disabled lives, but it offers an alternative way to understand agency and the constitution of queerness and disability. Similarly, we suggest that a queer performativity of madness suggests ways of understanding how a queer feminist politics might challenge normative systems of privilege in a manner not typically considered. By emphasizing the junctures between willful choice and mate- rial determinism, madness and mental illness, we might find not only new understandings of agency but also new ways for thinking of the viability of all kinds of subjects.

At the same time, much like Rand's analysis of the polemic's agency relies on Whiteness, the subversive possibilities of a queer performativity of madness also rely heavily on norms of Whiteness, both for Solanas and generally. Because of the norms of White femininity that Solanas was able to, at least somewhat, approximate, even as she was construed as mad, she was not read through the racializing logics that constitute men and women of color. Even a cursory examination of Western race politics reveals how forms of madness continue to perpetuate racist stereotypes. Angry and violent Black men consistently portrayed in sports (especially boxing) are men "in need of "trainers' who focus their talent toward victory" (Hill Collins, 2005,

p. 154). Similarly, the stickiness of tropes such as the "angry Black woman," which can interpellate all women of color who express emotion, suggest that the existence of a racist culture prevents many of the subversive possibilities for agency we 
are able to locate in Solanas's writing. In this way, there are certainly limits to the agentic possibilities of a queer performativity of madness. Queer performativity of madness, however, is another path to understanding the politics of agency at work in constructions of who fits in and who remains excluded.

\section{Declaration of Conflicting Interests}

The authors declared no potential conflicts of interest with respect to the research, authorship, and/or publication of this article.

\section{Funding}

Research was funded through a grant from the Hugh Downs School of Human Communication, Arizona State University. A version of this paper was presented at the National Communication Association Convention in November 2010.

\section{References}

The Andy Warhol Museum. (2006). Invoice. Pittsburgh, PA: The Andy Warhol Museum, Archives Study Center.

Baym, N. (1984). The madwoman and her languages: Why I don't do feminist literary theory. Tulsa Studies in Women's Literature, 3(12), 45-59.

Bennett, J. A. (2009). Banning queer blood: Rhetorics of citizenship, contagion, and resistance. Tuscaloosa: University of Alabama Press.

Berger, M. (2005, February 11). Arthur Miller, moral voice of American stage, dies at 89. The New York Times. Retrieved from http://www.nytimes.com/2005/02/11/theater/newsandfeatures/11cnd-miller.html?_r=1\&adxnnl=1\&ref=arthurmiller \&adxnnlx=1303907774-+Kyj2zmtQvFO0zesYmfI0w

Bruhm, S. (1996). Queer, queer Vladimir. American Imago, 53, 281-306.

Butler, J. (1993). Bodies that matter: On the discursive limits of sex. New York, NY: Routledge.

Butler, J. (1995). Contingent foundations: Feminism and the question of "postmodernism." In S. Benhabib, J. Butler, D. Cor- nell, \& N. Fraser

(Eds.), Feminist contentions: A philosophical exchange (pp. 35-57). New York, NY: Routledge.

Butler, J. (1999). Gender trouble: Feminism and the subversion of identity. New York, NY: Routledge.

Caminero-Santangelo, M. (1998). The madwoman can't speak, or why insanity is not subversive. Ithaca, NY: Cornell University Press. Campbell, K. K. (2005). Agency: Promiscuous and protean. Communication and Critical/Cultural Studies, 2(1), 1-19.

Chesler, P. (1977). Women and madness. New York, NY:Harcourt Brace.

Cixous, H. (1976). The laugh of the Medusa. Signs, 1, 875-893. Coffman, C. E. (2003). Framing Christine Papin [Film Review]. GLQ, 9, 415-428.

Coffman, C. E. (2006). Insane passions: Lesbianism and psychosis in literature and film. Middletown, CT: Wesleyan University Press. Cote,

D. (2001). Theatre. TimeOut New York. Retrieved from http://www.timeout.com/newyork/DetailsAr.do?file=/

theater/283/283.theat.upyour.rev.html

Deem, M. D. (1996). From Bobbitt to SCUM: Rememberment, scatalogial rhetorics, and feminist strategies in the contemporary United States. Public Culture, 8, 511-537.

Derrida, J. (1977). Signature event context. Glyph, 1, 172-197. Doyle, J. (2006, May-June). Warhol's women (one in particular). Gay \& Lesbian Review, 13, 32-33.

Eribon, D. (2001). Michel Foucault's histories of sexuality. GLQ, 7(1), 31-86.

Faso, F., McLaughlin, M., \& Henry, R. (1968). Actress shoots Andy Warhol cries "He controlled my life." Daily News, 49, 1, 3, 32.

Felman, S. (1993). What does a woman want? Reading and sexual difference. Baltimore, MD: Johns Hopkins University Press.

Foucault, M. (1988). Madness and civilization: A history of insanity in the age of reason (R. Howard, Trans.). New York, NY: Vintage Books.

Foucault, M. (1995). Madness, the absence of work. Critical Inquiry, 21, 290-298.

Gilbert, S. M., \& Gubar, S. (1979). The madwoman in the attic: The woman writer and the nineteenth-century literary imagination. New Haven, CT: Yale University Press.

Harding, J. (2001). The simplest surrealist act: Valerie Solanas and the (re)assertion of avant-garde priorities. Drama Review, 45, 142-162.

Harron, M. (1996). Introduction. In M. Harron \& D. Minahan (Eds.), I shot Andy Warhol (pp. vii-xxxi). New York, NY: Grove.

Heller, D. (2001). Shooting Solanas: Radical feminist history and the technology of failure. Feminist Studies, 27, 167-189.

hooks, b. (1995). Killing rage: Ending racism. New York, NY: Henry Holt.

Hill Collins, P. (2005). Black sexual politics. New York, NY: Routledge.

Huffer, L. (2010). Mad for Foucault: Rethinking the foundations of queer theory. New York, NY: Columbia University Press.

Irigaray, L. (1985). The sex which is not one (C. Porter \& C. Burke, Trans.). Ithaca, NY: Cornell University Press.

Lorde, A. (1984). The uses of anger: Women responding to racism. In A. Lorde (Ed.), Sister outsider: Essays and speeches (pp. 124-133).

Berkeley, CA: The Crossing Press.

Love, H. K. (2001). "Spoiled identity": Stephen Gordon's loneli- ness and the difficulties of queer history. GLQ,7, 487-519.

Marmorstein, R. (1968). A winter memory of Valerie Solanas. Village Voice, 35, 9-10, 20.

McGee, M. (1990). Text, context, and the fragmentation of con- temporary culture. Western Journal of Communication, 54, 274-289.

McRuer, R. (2003). As good as it gets: Queer theory and critical disability. GLQ, 9(1-2), 79-105.

Moore, M. S. (2000). Real art is murder. Retrieved from http:// salon.com

Rand, E. J. (2008). An inflammatory fag and a queer form: Larry Kramer, polemics, and rhetorical agency. Quarterly Journal of Speech, 94 , 
Rich, B. R. (1993). Manifesto destiny: Drawing a bead on Valerie Solanas. Village Voice Literary Supplement, 119, 16-17.

Ronnell, A. (2004). Introduction. In V. Solanas (Ed.), SCUM Man- ifesto (pp. 1-31). New York, NY: Verso. Schlichter, A. (2003). Critical madness, enunciative excess: The figure of the madwoman in postmodern feminist texts. Cul-tural Studies $<=>$ Critical Methodologies, 3, 308-329.

Schlichter, A. (2007). "I can’t get sexual genders straight": Kathy Acker's writing of bodies and pleasures. Postmodern Culture, 17(2). Retrieved from http://pmc.iath.virginia.edu/text-only/ issue.107/17.2schlichter.txt

Sedgwick, E. K. (1990). Epistemology of the closet. Berkeley: University of California Press.

Smith, H., \& Van der Horst, B. (1977). Valerie Solanas interview.

Village Voice, 22, 32.

Solanas, V. (1966, July). For 2ф: Pain. Cavalier Magazine, pp. 38-40, 76-77.

Solomon, A. (2001). Whose soiree now? Village Voice. Retrieved from http://www.villagevoice.com/theater/0108,solomon, 22438,11.html Stockton, K. B. (2007). Feeling like killing: Queer temporalities of murderous motives among queer children. GLQ, 13, $301-325$.

Walsh, J. (2002). "The strangest pain to bear": Corporeality and fear of insanity in Charlotte Mew's poetry. Victorian Poetry, 40, $217-240$. Warner, M. (1999). The trouble with normal: Sex, politics, and the ethics of queer life. New York, NY: Free Press.

West, I. (2010). PISSAR's critically queer and disabled politics.

Communication \& Critical/Cultural Studies, 7, 156-175. 